\title{
Glauber e o cinema escrito de Eduardo Coutinho
}

\author{
Fernão Pessoa Ramos' \\ https://orcid.org/0000-0002-7812-0489 \\ I - Unicamp \\ São Paulo (SP), Brasil
}

Resumo: O que a sensibilidade, meio brincalhona, meio algoz - o olho ciclope do Glauber-profeta traz para o filme Câncer (1968) quando nos apresenta o personagem-personalidade 'Eduardo Coutinho', definindo-o como 'homem do caderninho'? Glauber e Coutinho coincidem na desconfiança da escrita e da teoria. Querem abarcar a expressão numa identidade-de-si, plenitude da sensação e da intuição, gesto e voz, reino da substância fonocêntrica. Nosso ponto é atentar, em Eduardo Coutinho, para a instância articuladora/ordenadora que se acopla no modo livre de expressão da linguagem falada. Assim, ela faz diferença e desconstrói, de fora e no modo diferido, a coincidência do outro 'popular' na comunhão da 'voz-face'. É essa instância que desafia a congregação na alteridade, introduzindo uma decalagem de raiz que modula a encenação coutiniana. Promove uma valoração diferida, impedindo a cristalização da empatia como fundo transparente da comunicação.

Palavras-chave: teoria do cinema; cinema documentário; mise-en-scène; Eduardo Coutinho; Glauber Rocha.

Abstract: Glauber, and the writing mise-en-scène apparatus of Eduardo Coutinho - What kind of sensibility, half trickery, half-serious, the cyclops eye of Glauber Rocha brings to the scene of Câncer (1968), when he presents the personality-character 'Eduardo Coutinho' as the 'man of the notebook'? In his creative 'mise-en-scène,' Glauber somehow mimics the way Coutinho himself, some years later, will deal with actors' performances in another scene device called 'documentary film.' Glauber and Coutinho coincide in the distrust of writing and theory, as opposed to intuition and expression. Our point is to pay attention, in Eduardo Coutinho films, to the apparatus engaged in the search for identity, by the spoke expression of the social 'otherness' named 'povo' ('the people'). The ordering mode of Coutinho's documentary mise-en-scène deconstructs this 'otherness,' reducing the phonetic substance of voice as pure communion.

Keywords: theory of cinema; documentary cinema; mise-en-scène; Eduardo Coutinho ; Glauber Rocha. 
Colocado diante do compromisso de escrever (...) sinto-me angustiado além da medida. No meu caso, independente de neuroses temporárias ou permanentes, esta dificuldade tem a ver com a escolha do documentário.

E. Coutinho (COUTINHO, 2008)

Sócrates, aquele que não escrevia.

F. Nietzsche (apud DERRIDA, 1973)

Podemos notar uma ambiguidade na relação de Eduardo Coutinho com a escrita, manifesta em diversos momentos de sua vida. Seria por isso que seu cinema parece se basear na fala, na expressão de afetos pela entonação da palavra, em oposição ao modo da escrita? O dilema talvez tenha raízes em episódio que reforçou este aspecto: sua participação no longa Câncer, de Glauber Rocha. Câncer, rodado em 16 mm, agosto de 1968, em apenas quatro dias, é obra feita no sopro estilístico do cinema direto, dirigido num momento de encruzilhada, quando a geração mais velha do Cinema Novo encontra a contracultura. Drogas, a posição da mulher, a questão racial, a militância de esquerda, os dilemas com a representação do popular, são temas presentes em Câncer, sempre através de personagens e situações ficcionais. A narrativa desenvolve personagens construídos na tensão entre personalidades-tipo artificiais e a personalidade concreta da experiência de vida, em cada um dos atores e amigos que participam do filme de Glauber. Eduardo Coutinho foi uma das pessoas escolhidas para encenar sua personalidade natural, a ser distendida na mise-en-scène da tomada.

Para nosso interesse, a singularidade da situação está na proposta de encenação glauberiana em Câncer que parece remeter, em sua similitude, ao Coutinho diretor, conforme se afirmará décadas depois. Antonio Pitanga, Odete Lara, Hugo Carvana, atores centrais do Cinema Novo, desenvolvem personagens no filme. Estão cercados de 'pessoas artistas', ou artistas amigos, não atores, interpretando na cena um misto de personalidade natural e personagem: além de Eduardo Coutinho, os 'amigos' José Medeiros, Luiz Carlos Saldanha, Hélio Oiticica, Rogerio Duarte, Zelito Viana, Tineca e Bidu (da Mangueira) encenam no filme. Algumas tomadas foram feitas na casa de Hélio Oiticica. A mistura tem um resultado: personalidades pessoais, expressando comportamentos e expressões fisionômicas cotidianas (tanto de atores, quanto não atores), vêm para primeiro plano e se misturam na espessura rala de personagens criados por Glauber na improvisação. Durante a mise-en-scène eles se configuram em 'tipos' sem densidade psicológica: o malandro, o homem do povo, o intelectual marxista, o racista autoritário, o machão, o delegado, a mulher casada que trai etc. A proposta do filme é radicalizar o cinema feito pela cena, com encenação livre, se consumindo na tensão do 'direto' e numa estilística de corpo a corpo com o mundo. Os atores em Câncer 'furam' personagens e personalidades 
reais, encavalando vida com atuação, dirigidos na tensão do que chamamos 'encenaçãoconstruída', aqui flexionada pelo universo autoral glauberiano. Trata-se de um movimento de criação que, mais tarde, também Coutinho irá desenvolver em sua carreira (RAMOS, 2015) - embora em outro dispositivo de cena, num outro tipo de narrativa fílmica, chamada documentária (nela a dominante é inversa, virada pela encenação no mundo).

Glauber menciona, em entrevistas, a intenção de manter, no filme, a duração original em cada plano do negativo que cabia no chassi da câmera $16 \mathrm{~mm}$, cerca de doze minutos em cada tomada. Seriam então 27 planos de 12 minutos, numa proposta com claras conotações straubianas, explorando, como diz, a "resistência da duração", embora, evidentemente, sem a ascese do original. Glauber teve contatos com os Straub nos anos 1960 e conhecia o trabalho da dupla. A Crônica de Anna Magdalena Bach é o do mesmo ano que Câncer (Sganzerla seguiria a mesma estratégia em 'Sem Essa Aranha', 1970, longa de ficção com 17 planos sequências). A disposição dos planos-sequênciastomadas em Câncer, seguindo a duração do negativo no chassi, acaba não ocorrendo de modo exato e diversos planos perdem a duração original na montagem. O fato é que o filme, montado no exílio em 1972, trabalha com longos planos sequências e a estilística dominante da obra responde ao tipo de interpretação, historicamente inaugurada pelo documentário 'direto'/'verdade'. Atores e não atores levam o 'jogo de cena' em Câncer através da vida, como comportamento, mesclando personalidades naturais carregadas e personagens-tipos criados por Glauber. A encruzilhada construída é tão fascinante quanto singular em sua época, se a cotejarmos com outros filmes do 'novo cinema' internacional e latino-americano. Glauber é um furacão, uma sensibilidade ambulante que sintetiza sua época. Em pleno ano de 1968, estica ao máximo os desafios da nova estilística com experiências diversas nos dois longas que realiza: Câncer e, logo em seguida, O Dragão da Maldade Contra o Santo Guerreiro, em outro esquema de produção. Em Câncer, Glauber permite-se dar vazão a experiências narrativas e de mise-en-scène mais radicais daquelas encontradas em O Dragão da Maldade, vistas pelo grande público nacional e internacional.

A sequência com Coutinho em Câncer não é aleatória. Reúne dois dos principais diretores do cinema brasileiro do século XX, um dirigindo e outro sendo dirigido. Câncer embaralha de forma provocativa níveis de encenação ('construída' e 'direta') fazendo uma mistura em que todos personagens aparecem puxados na fala (improvisada a partir de um tema, ou traço de personalidade). Os atores não atores ficam numa espécie de presente torcido pela tomada que depois será picotado em planos longos e sugado no funil temporal do filme. Todos são atores de si, pois os tipos se abrem nessa maneira. Eduardo Coutinho vai interpretar em Câncer um personagem que mistura o que Glauber, de alguma forma, acredita ser a sua personalidade, definida no filme como 'o homem do caderninho'. É aquele que fala sem parar durante sua participação, sobre o caderninho e seu conteúdo, a forma escrita. Além de Coutinho encarnando o intelectual comunista fixado na escrita, temos a presença de figuras chaves do tropicalismo como Rogério Duarte (recém-saído 
da prisão) e Hélio Oiticica, numa parceria inédita com Glauber que foi além da atuação cênica do artista plástico. Câncer é um momento singular de encontro entre Oiticica e Glauber, duas personalidades fortes, centrais nas artes plásticas e cinematográficas do Brasil na segunda metade do século XX. Mostra o diálogo da obra, e da pessoa, de Glauber com o horizonte do tropicalismo que Oiticica e Duarte encarnam e a referência presente do neo-concretismo (DUARTE, 2012). O filme traz tipos-atores interagindo com tipos-personagens, como Pitanga que é o homem-do-povo; Odete Lara a mulher-de-classemédia; Hugo Carvana, que oscila no tipo, interpretando o marginal-brasileiro. Em outro modo de encenação, pois não são atores, estão os 'artistas-amigos', 'puxados' em cena para mesclar personalidade cotidiana ao tipo-personagem: Coutinho faz o intelectual comunista às voltas com a expressão escrita e sua ordenação contra a práxis; Oiticica contracena um tipo de elite, arrogante, mais tímido, tendo ao fundo um Rogério Duarte, também arrogante, racista, que interfere mais em cena (ambos contracenam com o Pitanga popular, revoltado e humilde, que naturalmente domina a encenação nas sequências que participa); José Medeiros faz o intermediário de mercadorias roubadas; Saldanha faz o rapaz que traiu o marido Carvana com Lara. No final, Duarte e Oiticica são mortos por Pitanga, após reiteradamente humilharem o homem do povo que este representa. Carvana também é assassinado pelo personagem de Pitanga. Na sequência de seu personagem, Coutinho aparece como um ser oprimido, justificando-se em mentor da ordem, face a um Carvana tipo investigador, agressivo e debochado.

$\mathrm{Na}$ duração estendida dos planos-sequências de Câncer, o som se arrasta fora de rotação em alguns momentos (as vozes engrossam). Parece querer dilatar a extensão e a escansão do presente da cena. A expressão pinga num jorro, sem a marcação de falas propositivas no modo dialógico. Fala-se muito e, no entanto, o que sai é uma pasta melada, grudada na substância não temporalizada, que parece impedir a palavra de aderir ao referente como exterioridade designativa. Na fala de Coutinho em Câncer, o procedimento de 'vagar' não gruda e ele fala rapidamente, engolindo palavras, num modo que quase não conseguimos distingui-las. O procedimento do 'vagar' sonoro da fala (espécie de câmera lenta do som), bastante raro no cinema, foi decorrência de um problema técnico involuntário na sincronia do som direto. O 'ralentir' (vagar) sonoro casa com a duração longa dos planos que estouram a duração. Embora sem intencionalidade original, o problema foi acolhido por Glauber com criatividade, durante a montagem do filme em 1971 em Cuba, e incorporado como procedimento estético-estilístico. A duração do plano longo pega assim na matéria da fala e cristaliza no vagar da voz a dilatação espaço-temporal da cena, que derrapa ao decupar a fala pela sintaxe. A extensão já exacerbada do plano-sequência encontra com a fala escorrida, repercutindo mais forte a oscilação entre personagem e personalidade de si que a duração esticada provocada. 
O que a sensibilidade, meio brincalhona, meio algoz - o olho ciclope do Glauberprofeta - traz para a cena de Câncer, quando nos apresenta o personagem-personalidade 'Eduardo Coutinho'? O que este olho-autor, o sujeito-Glauber pela personalidade 'Coutinho', vê na cena que o faz encontrar um personagem? Coutinho, apesar de seis anos mais velho que Glauber, irá desenvolver (vista de 1968) uma carreira tardia, atingindo seu auge só na virada do século XX, com mais de sessenta anos (MATTOS, 2019; LINS, 2004). Glauber sempre foi muito precoce e morreu cedo, aos 42 anos. Na época de Câncer, Coutinho era apenas um cineasta periférico no grupo nuclear do Cinema Novo. Possuía vínculos oscilantes com o PCB (Partido Comunista Brasileiro) e foi atuante, na cola de Leon Hirszman, nos Centros Populares de Cultura da UNE, antes de serem dissolvidos pelo golpe militar de 1964. Era também o diretor de um longa do CPC não finalizado (a primeira versão de Cabra Marcado para Morrer, 1964) e costumava ser chamado para trabalhar em roteiros do grupo. Na época, 1968, esteve envolvido na direção e roteiro de $O$ Homem que Comprou o Mundo (provavelmente um dos motivos para estar no set de Câncer), uma iniciativa do novo cinema (pelo lado de Zelito Viana/Mapa Filmes, que também faz uma ponta em Câncer e produziu O Dragão da Maldade), para atingir o grande público. Inicialmente, a direção desta comédia seria destinada a Luís Carlos Maciel, mas acabou nas mãos de Coutinho que, como diretor substituto num trabalho de encomenda, nunca gostou do resultado - embora tivesse assim dirigido seu primeiro longa completo.

De toda maneira, é estranho ver Coutinho, em 1968, sendo submetido (é a palavra certa, para o tipo de encenação que sofre) pelo grande diretor de sua geração, em procedimento similar - de entrelaçamento da personalidade na tomada - a que submeterá alguns de seus personagens e que atinge seu paroxismo em Jogo de Cena. Neste sentido, talvez não seja forçar a 'trouvaille' dizer que Câncer e Jogo de Cena são duas faces da mesma moeda. Em sua forma de centrifugar personalidades pelo voo livre de personagens, abrem-se numa espécie de rompimento que faz a fissura da cena. Coutinho, torcido no personagem do militante ortodoxo comunista que se nega ("não sou militante"), surge em Câncer pela experiência singular da situação 'para-si', papel seu com personalidade criada (nos longas posteriores que dirigiu fará sempre na cena o papel 'de-si', ou o 'si-mesmo'Coutinho-documentarista). É significativo que a brincadeira de Glauber, de recortá-lo no modo de militante comunista mais tacanho, seja talvez lembrança dos tempos do CPC, brincadeira com a figura do 'pai espiritual' Leon Hirszman. Mais ainda, o Coutinho personagem de Câncer, além de militante confuso, é um intelectual (um 'teórico') que anota tudo em seu 'caderninho' e nega a práxis ("sou teórico e tenho um caderninho"). É obcecado por seguir regras e tem como projeto um Brasil transformado não pela revolução social, mas pela preocupação com a ordem ("eu não quero anarquizar, quero que as coisas sejam feitas com ordem"), em seguir horários na organização rígida da práxis 
("tem que ter os horários... três e quinze é três e quinze... a polícia também tinha que ter um caderninho, tem que ter uma repressão organizada e uma revolução organizada"). É por aí que caminha o norte da improvisação livre de Coutinho como o militante que é teórico e que tudo escreve, registra, ordena, classifica, o 'homem do caderninho', estimulada pelo diretor de cena Glauber Rocha.

No caderninho, o personagem-Coutinho diz que também não há 'nomes', nem 'notas'. Não há conteúdo. É um caderno/livro que fica sem completar a função designativa da escrita: não refere personalidades, ou fatos, como exterioridade particular. Por outro lado, e é esta sua função, serve como dispositivo de escrita que organiza a vida, negando o modo livre de 'anarquia' que tem a práxis aleatória como norte. Se o caderninho não tem nomes, nem fatos, o personagem também não entrega o conteúdo para seu interrogador, meio policial, meio marginal, interpretado por Hugo Carvana. O caderninho funciona como um grande dispositivo organizador. Se não tem nada, apenas estende o tempo em seus pedaços no modo da temporalização pelos horários, preocupação da medida no personagem que assim desafia o tipo de cena em que encena. O tempo é 'chronos', e não 'kairós', organização pronta para o dispositivo da ordem. Assim decupado, é a espécie arquetípica de um aparato que organiza, dispõe e é presente sem diferir, em oposição ao modo fílmico da intuição na tomada. Aqui ele se opõe à expressão livre do malandroboçal Carvana, que ridiculariza, com evidente beneplácito do ponto de vista narrativo, a intenção sistematizadora da escrita do caderninho e seu sujeito intelectual logocêntrico. O caderninho, em si mesmo, é o 'livro da natureza' dos filósofos racionalistas, aqui reduzido como 'livro' da natureza comunista, focado na militância do pensamento.

O personagem de Coutinho, na sua sequência, surge numa imagem em primeiríssimo plano, esmagado num modo sufocante. 'Teórico do caderninho', Coutinho está efetivamente oprimido na contra-cena com Hugo Carvana. Este trabalha numa interpretação carregada pelo lado boçal, fazendo um tipo autoritário-agressivo, provavelmente estimulado pela direção de cena. Possui esse tom agressivo, com tonalidades machistas e racistas, diluídas pela sombra do deboche, tão comum em filmes do Cinema Novo e também no Cinema Marginal. Coutinho responde com o tipo característico que carregaria na vida, olhando para dentro, para baixo, falando entre os dentes, com frases curtas e sincopadas, querendo avançar o sinal do discurso por ele mesmo, sem interrupção. Olha seu interlocutor, mas não enxerga realmente, não está dentro do modo dialógico. Tenta avançar assim, mas não consegue. Sempre que o personagem começa a divagar para estabelecer no pensamento camadas sobrepostas de raciocínio dedutivo, características de seu ser 'teórico', é brutalmente interrompido pelo fluxo Carvana. Este não quer conversa, não quer pensamento articulado, quer empatia ou embate, gozo ou exasperação, catarse no corpo a corpo da cena.

Carvana incorpora o personagem glauberiano, Coutinho é o ponto fora da curva, o freio de mão puxado. O resultado é um Coutinho atropelado, acuado, jogado às cordas, 
ridicularizado ao tentar afirmar a lógica do caderninho que é a lógica da escritura, face a exuberância da expressão fonocêntrica, coincidência no jorro da fala com o gesto, pelo corpo, em modo de enunciação. Não há redução, ou diferença, que introduza fissura ou recuo na coincidência verborrágica de Carvana. Apenas seu discurso preponderando a experiência narcisa da palavra própria ('própria' na definição mesma da coincidência de presença no ser que profere). O freio de Coutinho é o freio do caderninho e sua escritura como ordenação de fora. Faz uma viga na parede, mas não vinga, pois fica embaixo e é oprimido. Ali embaixo, no quadro, não há fonte para suplementar a fala, mas apenas um discurso entre os dentes, engolido pela própria timidez, que também não faz preponderar a divisão (a divisão da escrita) que anuncia. Este certamente não seria o momento, em 1968, com o país ardendo em busca de empatia e Glauber no auge da força criativa. Mas o desafio desde aí se coloca e Coutinho, de certo modo, será quem irá mais tarde saber como fazer valer a ordenação e o freio de mão, sem comprometer o jorro da coincidência com o 'outrem' - contra o conceito e pela intuição e a sensação - que tanto valoriza sua geração.

Em Câncer este 'outro' é encarnado pelo personagem de Pitanga. Ele apanha muito ao tentar fazer valer a expressão popular, expressão que na cena é reduzida pela frieza (Lara), pela agressividade violenta (Oiticica e Duarte), ou pela boçalidade (Carvana). Tem sua voz/fala negada continuamente pela emissão dominante (voz do filme) da articulação narrativa. Glauber lhe concede, no entanto, o momento sublime de Câncer: um encontro de extrema delicadeza sensual, ponto alto na imagética glauberiana, no qual Pitanga rodopia na plenitude de uma intersubjetividade que, só aqui no filme, se completa por inteira na expressão, sem travas. Do outro lado do encontro, está sua companheira de classe social, Tineca, atriz natural, também negra e popular. Uma ágil câmera em primeiro plano se fixa em ambos que, em plano-sequência, fazem um balé de posições com corpos que se invertem em constantes movimentos de $180^{\circ}$, num belíssimo movimento carregado por uma melodia doce que acentua a comunhão entre os personagens.

É interessante, igualmente, notar o personagem tipicamente popular que assiste abismado a sequência entre Coutinho e Carvana, segurando um bule de café, pronto para cumprir seu papel como subalterno, ao lado de uma grande cruz que é empunhada pelo 'delegado'. Tem posição simultaneamente serviçal e um olhar carregado de doçura cativante, com uma ponta inocente de curiosidade para a cena. Expressa espontaneamente uma composição de imagem-câmera fílmica que só a direção de um grande artista, como Glauber, consegue extrair da interpretação do ator natural (Coutinho irá mostrar também este talento em sua carreira). A câmera percorre a expressão do outro-popular com evidente prazer da descoberta e pousa com suavidade, compondo o quadro. Assim como outros personagens 'populares' no cinema de Glauber, aqui o ator popular tudo assiste, pairando no ar com a inocência do ser que basta a si-mesmo, experiência pura que não necessita do dobrar reflexivo sobre a vivência do evento para fazer o valor. Mostra a vontade de instaurar, sem peias, a decalagem da diferença pela expressão que coincide sem necessitar da designação na ênfase - carregada na sequência pelo personagem de Carvana. 
Coutinho, ao encarnar no recuo de seu personagem a lógica da escrita e da gramática, que se debruça e reflete, mostra por que é figura paralela e tardia no Cinema Novo e por que teve de esperar quase meio século para encontrar a veia boa de seu cinema. Uma veia que tem sua configuração num modo 'pós-cinema novo', num modo 'pós-moderno', de dialogar com o outro-popular. Uma estética que, ao carregar o dispositivo para disparar na tomada e furar a identidade da fala no corpo da voz, expressão fonética, faz jus ao caráter tardio. Traz o recuo implantado por um dispositivo que, reiteradamente esboçado, é, afinal, descoberto (desvelado) numa espécie de maneirismo que mostra o artista no pleno domínio de sua arte no final dos anos 2000. Assim, Coutinho dialoga com a perspectiva glauberiana numa posição inédita, pois este também é um artista que no final se cansa - e por isso mesmo pôde ser visto como líder e profeta. Algo que seus colegas de geração não souberam, ou necessitaram, estabelecer, por terem encerrado antes a carreira - ou por terem tido tempo para se repetir amadurecendo, numa conformidade que ele não possui. Em Câncer, a imagem do popular empático (aquela imagem que será do primeiro fôlego no cinema de Coutinho) está lá, segurando um bule e olhando a vida como pássaro que paira e passa. Ele, homem-do-caderninho, está mergulhado, quase de olhos fechados, afundado cegamente para dentro, nas elucubrações das asserções propositivas do pensamento em cascata. A improvisação de Coutinho que Câncer promove intuitivamente (pois é assim que ela pode ser pensada), e destaca como o pulso de sua arte futura, é simultaneamente estética (no sentido literal do termo) e cercada por preparações, finalidades e intencionalidade, pronta para conquistar uma identidade que sabe não existir, mas que se vislumbra, exatamente por poder negar a regra que necessita para assim se impor.

O 'caderninho' é a lógica da medida que faz o valor do diferente, a estratégia do acuado. Restringe Eduardo Coutinho para escapar do suplemento na expressão, o jorro pulsional ressentido que vibra na fala de Carvana. É por ele que vai se vingar e construir a diferença que, com o tempo e os anos, faz-se estabelecer como necessário (Glauber aparentemente também havia se dado conta, como podemos sentir depois nas improvisações de Claro). É sua contraproposta ao desbunde contracultural que cerca Câncer e que transpira pelos poros da narrativa. A desmesura, o absoluto reinado das emoções fartas, gordas de espírito no encontro com o si-mesmo, ecoa nos personagens mais completos e aquele de Carvana não é exceção. Eles carregam o excesso da desmedida e a degustam com inegável prazer no reino da autoridade, que concede a coincidência com o si-mesmo, liberto pela exaltação da fala. Encarnam o pulsar de um 'de-dentro' que flui com potência pela representação, como complemento da expressão, estabilizando e satisfazendo a presença na identidade do 'consigo-mesmo'. As falas passam então como 
um jorro, sem cristalizar discurso como forma. São emblemas de empatia. O homem-docaderninho é ridicularizado por encorpar o de-fora que trava e lança a intuição na fenda e faz o recuo, a recusa de ser complemento na satisfação pela redução da alteridade. É o reflexivo, a consciência-de-si. O jogo limpo é daquele que, com um passo atrás, abre a porta e deixa passar o monstro disforme, mas não comunga sua passagem e compõe uma forma de expressão que se afirma como logro - ela mesma é 'truque da escrita'. Fora disso é só suplemento de identidade, sem a enquadrar diferença, é demanda ansiosa de exaltação pela comunhão.

O personagem da escrita e do caderninho em Câncer aparece negando a vida em sua potência de vontade, explosiva e livre. Faz o personagem do sistema ou, pelo avesso, do sistema comunista, da militância comunista, associada à escrita que tolhe a expressão. O personagem de Coutinho seria representante da visão que Glauber possui, naquele momento, da parcela de sua geração que abandonou o 'desbunde' (local em que, de certa forma, está se situando) e aderiu à disciplina da luta armada, ao seu 'caderninho' com horários, regras e pontos de encontro? Que aderiu aos rígidos códigos de conduta, regidos pelo caderninho da vida clandestina e as também estruturas partidárias do centralismo democrático? Duas metades estão colocadas: onde tudo é anotado, sistematizado, cumprido e onde a responsabilidade impera; e o espaço da vida à descoberta, em que experiência e expressão são oscilantes e sem rumo, gritadas, avacalhadas, desbundadas. Nós estamos querendo acionar a posição de uma terceira metade da representação (e que certamente vai fazer com que a conta não feche): a metade da infinidade, que traz consigo, ao se dividir por sua vez, as oposições entre o de-dentro e o de-fora, entre identidade e alteridade, entre suplemento e diferença, entre presença e diferimento, entre fala e escrita, entre caderno e o livro do texto-porvir (BLANCHOT, 2005). Ao se deslocar do local de encontro na comunhão, previsto inicialmente nas duas metades, esta última parte se vê a si no embate pelas costas, num movimento que ascende a desconstrução. Em outras palavras, as metades simples do sistema seriam o transe e o encontro no êxtase e na comoção, de um lado; e o câncer do sistema e da organização (do comunismo militante), a coordenação da escrita que faz o caderno, de outro. Nosso ponto é que os lados não se misturam assim, em oposição simples, negação ou reconciliação de uma tese que o filme não expõe em nenhum momento. Permanecem como idas e vindas num jogo que se figura na instabilidade. Não é o objetivo do filme asserir uma ordem, nem caminhar para a congregação explicativa.

Na expressão livre da cena (que é o esforço onde se concentra Glauber nesta obra) situam-se os campos que o profeta diretor se coloca: o da pulsão e o da redenção, levando essas duas partes, aparentemente irreconciliáveis, para um buraco no qual podem vibrar entre si, sem resolução, até que a diferença as faça retornar, para fazer valer a potência de um novo iniciar. Coutinho está como a metade que é própria do todo, em sua multiplicidade inerente. É também aquela metade que decompõe, como diferença 
na raiz, aquela que valora pela força da afirmação restringente, que afirma o diferir. Este lado é o 'outro' do próprio sistema e que tem hélice para se negar em si; o 'outro' que ainda irá retornar no campo do mesmo até que Glauber - que certamente quer para si a voz vibrante - descubra, em sua vez de profeta, o modo restringente como intensidade e vida. Coutinho, certamente o mais esforçado e compenetrado dos dois, também dará sua volta ao chegar lá - volta que não caberá a Glauber ser espectador, pois antes disso saiu de cena. Por ser tardia, a volta coutiniana corre em dupla direção: está lá desde o início, mas faz às vezes de voltar pelo mesmo percurso, quando já tem claramente para si que o caminho está destruído pela frente. Para se recuperar da potência esvaziada da empatia terá de modular, pacientemente, desconstruir sem edificar, e recuperar no movimento a diferença que em Câncer se respira no primeiro turno, tão naturalmente.

O singular é que, ao caracterizar assim seu colega cineasta, a intuição glauberiana (como as intuições daqueles que podem profetizar) acerta na mosca pelo inverso, acerta na distensão pela ironia. Pois Coutinho passará o resto da vida a edificar seu cinema futuro, negando, no que mais tarde chamará de 'dispositivo', a lógica do 'caderninho'. No entanto, a negação tem o pé preso e seu efeito é fumaça, não só sobre si, mas principalmente sobre a expressão daquilo que busca no entrelaçamento que inaugura - a cena madura de sua obra documentária. 'Intelectual comunista', teórico que possui 'caderninho', Coutinho demora para aprender a levar o caderno no bolso sem culpa, sem precisar recitar as categorias no modo que faz em Câncer. Talvez seja castigo de profeta, a maldição do caderno na cena que "para sempre te acompanhará", cajado que só quem carrega consegue bramir, praguejando imprecações.

\section{4}

Coutinho se auto define na primeira pessoa em Câncer. No misto do delírio profético de Glauber sobre a 'personalidade-Coutinho', o que significa, para Coutinho e para seu futuro dispositivo documentário, o 'ser' teórico que se supõe na escritura do caderno/livro? Há uma dicotomia em Câncer que, em certa medida, é a mesma do discurso disperso de Coutinho sobre sua própria obra. Glauber e Coutinho coincidem na desconfiança da escrita e da teoria-pensamento, como oposição à expressão de uma identidade-de-si na plenitude do gesto e da voz, reino da fala e da expressão fonocêntrica. A escrita é matéria fria da ausência, da substituição, do parasitismo da citação, da falta e da inscrição do de-fora. Nela, o campo do emissor que expressa é dilatado até a ausência e o repique da expressão, fundado na presença, é minado. O caderninho do militante Coutinho não tem nomes, nem notas, portanto não 'nomeia-designa', nem 'anota-registra', numa similitude da função referencial vazia, mas organizadora e modular, que se distancia da expressão fonocêntrica como designação da identidade na ilocução. É a escrita que funda o campo da diferença ao inscrever a reiteração (como repetição infinita do significado), rompendo 
a inscrição pela presença, o corpo voz/fala que enuncia no leque da performance ilocutória. O modelo finalista do livro-caderno, como aparato ordenador e deslocador da presença enunciativa (no regime da citação ou do arquivo, por exemplo), parece fechar e diluir a tensão mais anárquica e aberta da vida na expressão - 'carne' do corpo na voz, 'quiasma' ou 'entrelaçamento' na dialética da alteridade, como quer certa fenomenologia (PONTY, 1984). Mas, nesta coincidência, a expressão supõe ao menos uma camada de identidade e cedo Glauber percebe as agruras deste caminho - um pouco mais tarde Coutinho segue. Uma identidade pressuposta que incomoda. O discurso dominante do Coutinho maduro sobre os dilemas com a escrita reflete esta percepção do esgotamento da identidade a que esteve preso no passado. As algemas da escritura são necessárias para enfrentá-la e ele se debate com elas. De certo modo, o homem-do-caderninho glauberiano é o resumo disto, oscilando para lá e cá, antevendo o dilema crucial no qual ambos se debatem ao refletir sua obra. Pois o movimento é esse, reflexivo, da consciência-de-si na direção de um encontro fraturado, revelando uma impossibilidade e sempre mais um degrau - aquele que instaura a fratura da consciência que é o próprio movimento da história, de diferençanegação do outro/outrem. É quem tem a potência para fazer a hélice girar e o espírito do tempo mover, para nos atermos ao horizonte da dialética idealista.

Mas nosso ponto é atentar, em Coutinho, para a instância articuladora/ordenadora que se acopla no modo livre da linguagem falada, como diferença que explora, de fora, a coincidência do mesmo que agora não mais se sustenta. Caso acople, para negar-se e fazer valê-la, está numa aparente contradição. Pois seu valor, literalmente, não se dá no por-si e este é ponto nodal para apreendermos seu cinema. Para valer sua liberdade, Coutinho precisa da escritura que 'modula', pois é o que o faz oscilar e desafiar na congregação a alteridade, introduzindo a decalagem que detona a valoração radical da diferença e impede a estagnação cristalizada da consciência na coincidência do eu e da analogia. Em sua natureza mais própria, vê-se que a consciência não pode coincidir, pois traz falas de emissores muito distintos. Em seu sentido transversal, suturado pela escrita, de modo a ser performance enunciativa do mesmo, a enunciação é carregada nas modalidades diversas da ironia e outras disposições de decalagem, como a citação. A contradição e a consciência, oscilante ou atormentada, fazem, portanto, seu espaço. Em outras palavras, são as figuras do dispositivo cênico na tomada e no modo fílmico que instauram os sentidos reflexivos com os quais alimenta seu sistema valorativo e seu campo ético. Impedem a cristalização da mensagem analógica num fundo transparente de comunicação, pois sentem que este fundo é reflexo em vertigem, sem ponto final no sistema.

A acoplagem do sentido na fala, que a escritura coutiniana consegue descolar da ação corpo-voz, faz-se como fissura, como 'sopro' (DERRIDA, 1971). Descolada ela não afirma - e fica aquém da experiência de liberação da fala, na coincidência exaltativa do corpo. Dessa sensação de 'liberação' na exaltação (que também tem as formas da modéstia), vem os afetos com os quais se comunga. Mas, pelo modo dispositivo, a coincidência 
na expressão do eu que 'fala' recebe uma espécie de capa fria do ser, a capa da escrita, que enquanto técnica exterior faz o mesmo, o uno, se retrair pela ausência e pelo diferir. A reiteração, agora intercambiável e citável, intersubjetiva, desloca-se sob a forma do mecanismo cênico. Para escapar da expressão, o filme compõe-se, ou conquista-se. No módulo dispositivo, uma fala originária, em si mesma molecular, fica atrás e encosta, ou acopla, na da frente. É escudada num detalhado planejamento da cena e da interpretação que, se não o fecha (o 'eu' da fala), consegue ao menos liberar a capa de identidade da redenção. Instaura-se assim o modo articulador que, contra a espontaneidade, tenciona e se presta à fissura da comunhão na catarse. Assim podemos definir o movimento da cena coutiniana e a estética de seus afetos, sua 'aisthésis' propriamente.

É então, na economia da encenação, que o mecanismo do aparato funciona e Coutinho não sente necessidade de enfatizar a máquina azeitada da escritura. Desloca-se na superfície de sua estampa, pelas banalidades mais fáceis da reflexividade, tais como a imagem da câmera, a imagem do próprio corpo, a enunciação das condições de filmagem etc. Seu documentário vem de um cinema que vinga um valor, mas pela genealogia, na diferença. E é por ter de parecer prescindi-lo, valor, que a escrita deve absolutamente ser evitada para não se revelar - e por isto Coutinho debate-se com tanta ênfase, seja em entrevistas, seja em seu trabalho prático. Em certo momento da vida, no início, entregou-se com volúpia à escrita, como roteirista e crítico. Na restringência posterior, na teoria que seu cinema faz (o pensamento da ação que 'toma' na tomada, pelo filme), nada parecia aceitar que o pensamento seja fala, ou fala que não quer deduzir pensamento. Mas, na verdade, o homem que pensa, e não fala, o traço do personagem de Câncer que Coutinho traz no âmago de seu dispositivo de cena, é quem monta o filme para soltar a voz, atropelar a dedução e trazer empatia. É ele que está lá, no fundo. Mas não é só, e, por isso mesmo (ou para isso mesmo), a escritura é pedra no sapato, pois ao abrir se faz fenda, diferença, intervalo, espaçamento - e nega o homem. É em sua fissura que respira a voz e seu som, e é na face dela-outrem que ele, homem, se afirma, negado. A intuição da face-outrem ancora o procedimento estético e fende a porta da sensação, a enquadra num cogito-previsão que, na arte do filme, tem forma: decupagem e encenação. É forma de criação que Coutinho conhece bem, pois roteirista experiente, embora não a veja exercer sua obra. A transcrição da fala é engolida pela pressão da voz como fenômeno. Coutinho busca, nesse momento, a epifania, que é quando se descobre autor. A ordem da cena (pois de ordenação se trata) não é natureza pura ou expressão espontânea. É precisão do dispositivo, escandido, e assim se abre pela memória que fala nas modalidades que vão até a canção - fluxo da enunciação desabrochando na fôrma aleatória.

No auge do domínio estilístico, primeira metade da década de 2000, amadurece o procedimento (a partir de Santa Marta/1987 e, já maduro, em Santo Forte/1999; Edifício Master/2002; Peões/2004 e O Fim e o Princípio/2005) e depois o desmonta num modo maneirista, como fica claro na trilogia Jogo de Cena/2007, Moscou/2009 e Um Dia na Vida/2010. Assim a fala do corpo é preparada, bem dobrada, torcida, para entrar 
na caixa onde fica e abre-se só no espetáculo propriamente, no esplendor da cena, quando se inicia na tomada a duração que encena - para depois (mas ela está sempre lá, como forma, desde a cena) ser comprimida em filme. Se há um dispositivo para tal, Coutinho o criou, embora o fantasma do sistema sempre o assole. Por isso a negação, ou a afirmação pelos procedimentos menores da imagem imponderável. Inicialmente, ficaram para trás as articulações das asserções propositivas da voz documentária que justificam a montagem da imagem fílmica, os 'inserts', os contra-campos, os ping-pongs que fazem a sutura da narrativa clássica. Quer assim se liberar para a coincidência plena do ser, no aleatório da cena. Nada deixa sobrar no filme, que não sejam os restos mínimos necessários para articular o garimpo da pureza - filme sempre negado, mas sempre realizado, em toda a espessura necessária para o efeito desejado. Se Coutinho quer escapar de uma categoria exterior, seu cinema só a aprofunda, inclusive para poder negar o que é mesmo. Para poder alcançar, na cambalhota, a vereda da empatia começa em ser o outro: Coutinho, o mesmo, e sua 'voz do povo'.

A fala que não consegue ser fenômeno puro, a cena própria, já é dobra desde o início, sobre este outro que a dicção dispõe. O dispositivo serve para estampar como 'pura' uma dicção que se quer, reflexivamente, exibir. Toda ela é, no final, resquício de uma potência narcisista, a sua maneira própria de fluir, atropelando para frente o discurso em fluxo, sem justificação, sem redenção, sem conciliação. É um modo que quer ser unidade, coincidência, e deixa a Coutinho uma trilha estreita para fazer valer e justificar sua mão que, honestamente, cinde e fissura, marcando a alteridade do outro. $\mathrm{E}$, ao sair dele, outrem, precisa deixá-lo atrás como ser-para-si, para vingar o jogo livre da encenação: pela inocência duramente construída, ou desmontada na cena, sem a flexão da redenção ou a teia de aranha do julgamento. As mediações suplementares que garantem a identidade e a comunhão balançam no modelo da escritura coutiniana. Ele tem de fazer chegar diretamente, ao dispositivo construído, o que nele mesmo se inscreve (o que nele se escreve, deveríamos ter coragem de afirmar). E o desafio maior é o 'fazer chegar', sem verniz, o que já está lá e habita a tintura da preparação da cena mas que ela mesma, habitação, não expressa.

Para Coutinho, é o ser da imagem que busca, a ideia do 'outrem'. É o que de melhor ele, Coutinho, encontra 'neste seu olhar', visão deslumbrada de outrem que brilha no fundo do mecanismo. É lá que descobre a alteridade e nela encosta solidário, numa proximidade que quer máxima. E só assim que admite lidar com o filme, armadura da duração, no qual a aproximação é armadilha do sistema e gramática da escritura, no modo de um dispositivo. Ele tem, no fundo do maquinismo, uma imagem do 'dele-outrem' como pura ideia, pristina ou primeva. E que a multiplicidade empírica da ilocução da fala, marcada pela sujeição à alteridade, não a macule! Quer o popular-puro, este mesmo que respira no 'nele-outro', agora trazido para a cena, na plenitude de si, como ação no mundo. Vê-se então de onde partiu e onde chegou o homem do caderninho, em sua ojeriza pela escrita. Será que o alcance da empatia plena, o afeto puro buscado, servirá para cicatrizar a alteridade? Ao menos, em bálsamo, já deixa sua marca na atividade, pois a cicatriz da ausência e 
do diferir-lhe é constituinte e faz parte integrante do modo que usa para figurá-la. Coutinho carrega sua marca e quer mostrá-la no filme como algo natural, embora esteja sempre um passo atrás e nunca alcance a coincidência do intrinsicamente próprio, experiência dele no 'de-dentro'. Será que esta parte de si, forma de um movimento, torna seu cinema uma busca que não fecha? Se não nega o fosso entre voz e escritura, sempre quer trazê-lo para frente, na redução, como negação consumada.

Mas Coutinho não se afunda aí, numa espécie de masoquismo mal digerido, nem se paralisa por essa espécie de Medusa que fixa a plenitude no encontro com 'outrem'. A negação vira polo, afirma a diferença e paga o preço ativamente, indo fundo na composição exterior que quebra o feitiço hipnótico do suplemento. É na diferença da negação que sua obra encontra parâmetros para engajar-se e tomar impulso em modalidades da representação que não se fecham no outro. O personagem que se debate na cena de Câncer, encarnando o caderno que engole a força vital, dá o 'pulo do gato' no momento final de sua carreira. Enfrenta o encontro e assume, em modalidades diversas, a máquina intelectual da cena.

Fernão Pessoa Ramos é professor titular do Instituto de Artes da Unicamp.

fernaopramos@gmail.com

\section{Referências}

BLANCHOT, M. O livro por vir. São Paulo: Martins Fontes, 2005.

COUTINHO, E. O olhar no documentário (Carta-depoimento para Paulo Paranaguá). In: BRAGANÇA, F. Eduardo Coutinho - Encontros. Rio de Janeiro: Azougue, 2008.

DERRIDA, J. A escritura e a diferença. São Paulo: Perspectiva, 1971.

Gramatologia. São Paulo: Perspectiva, 1973.

DUARTE, T. C. Marcas do experimental no cinema: um estudo sobre Câncer. Dissertação de Mestrado defendida junto ao Instituto de Arte e Comunicação Social/Universidade Federal Fluminense, 2012.

LINS, C. O documentário de Eduardo Coutinho: televisão, cinema e vídeo. Rio de Janeiro: Zahar, 2004.

MATTOS, C.A. Sete faces de Eduardo Coutinho. São Paulo: Boitempo, 2019.

MERLEAU-PONTY, M. O visível e o invisível. São Paulo: Perspectiva, 1984.

RAMOS, F. P. What is documentary mise-en-scène? Coutinho's mannerism and Salles's 'mauvaise conscience'. Studies in documentary film, 8:2, 143-155, Routledge, 2015. 